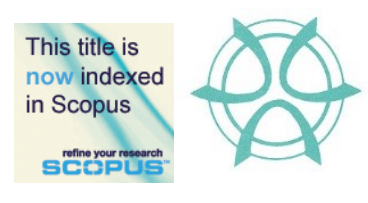

PLANNING MALAYSIA:

Journal of the Malaysian Institute of Planners

VOLUME 19 ISSUE 1 (2021), Page 77 - 88

\title{
COMPONENTS OF RIVER SUSTAINABILITY THROUGH COMMUNITY'S EXPERIENCES IN RIVERSIDE NEIGHBOURHOOD
}

\author{
Rohana Mohd Firdaus ${ }^{1}$, Mohd Hisyam Rasidi ${ }^{2}$, Ismail Said ${ }^{3}$ \\ ${ }^{1,2,3}$ Greenovation Research Group, Department of Landscape Architecture, \\ Faculty of Built Environment and Surveying \\ UNIVERSITI TEKNOLOGI MALAYSIA
}

\begin{abstract}
Communities of a riverside neighbourhood are essential in developing rivers into a sustainable environmental feature. However, their lack of awareness towards flooding and river pollution interferes with the river's sustainability. The disconnection with nature impairs sustainability; consequently, the river's value degrades. The awareness can be improved upon by focusing on riverside neighbourhoods. The residents would have some level of awareness due to living sustainably with the river environment. Therefore, this study aimed to explore the living experiences of a riverside neighbourhood's residents from a social perspective. Data were obtained through semi-structured questionnaires given to 121 residents, a focus group discussion and personal interviews. The questionnaires' responses were exported and analysed using Principal Component Analysis in SPSS to identify significant components that were pertinent to the aim. Six components were found and were clarified into three themes: 'river issues', 'river management' and 'river neighbourhood as a shared environment'. It has been found that exposure to river issues resulted in the residents exercising their resources to overcome those issues, and the cooperation between the residents and the stakeholder was essential in maintaining and achieving a sustainable river environment. The residents' connection with their neighbourhood was exemplified through their familiarity and neighbourliness. In conclusion, insight into the residents' experiences would provide a better understanding of river neighbourhoods, which stakeholders could consider in decision-making and planning to ensure the connection with nature is sustained.
\end{abstract}

Keywords: Community, riverside neighbourhood, living experience

${ }^{1} \mathrm{Ph}$. D Candidate at Universiti Teknologi Malaysia. Email: rohana.edengroup@gmail.com 
Rohana Mohd Firdaus, Mohd Hisyam Rasidi, Ismail Said

Components of River Sustainability Through Community's Experiences in Riverside Neighbourhood

\section{INTRODUCTION}

Anthropogenic activities have contributed to various environmental problems, including river degradation. Excessive domestic discharge due to human development has caused river systems to fail in neutralising pollutants before subsequent waste is discharged (Weil et al., 2018). Consequently, it causes river pollution, and the impact is experienced by the people, especially those that live close to rivers.

Despite the impact on people, many river studies are only focused on rivers' fluvial systems (Eze \& Knight, 2018; Lanzoni et al., 2018), disaster management (Deng \& Xu, 2018; Jiang et al., 2018; Rufat et al., 2015), and riparian ecosystems (Solins et al., 2018) that address flood measures. Focus on social aspects is still lacking. There have been studies since 2006 that focused on social benefits, but discussions on the benefits are still in infancy (Everard and Moggridgem 2012). As a social environment, the river still receives little attention (Åberg \& Tapsell, 2013), and so do the communities that live by it.

A recent study by Kumar et al. (2018) showed that there is still a need to consider human aspects in river studies. Riverside communities seemed to be apathetic towards the persistent river issues (Chan, 2012). Their apathy exacerbates the situation because when some of them use the rivers as disposal channels, they will be the most affected because of their proximity. There seems to be no appreciation for their river, which is as an entity in their neighbourhood. This study is essential in establishing better river environments that begin with the riverside communities because of these issues. Thereby, this study aimed to explore the living experience of a riverside community from the social perspective.

\section{RESEARCH PROBLEM}

Rivers are a versatile entity that can function as a place for human settlement, recreation and many others. Despite its association with humans since 2000BC (Mann, 1973), public awareness of the importance of rivers still lacks. Anthropogenic activities are still polluting the rivers in many countries, including Malaysia. Rivers are essential, and without them, Malaysia would not have its glorious history (Md. Yassin et al., 2010). Despite the historical significance, river pollution is still a severe issue in this country. One of the most recent instances of pollution happened to Johor's Kim Kim River in 2019. The pollution, which put the surrounding communities' health at stake, was found to be due to chemical wastes disposed of by parties that acted irresponsibly and illegally. Also, the risk of rivers becoming a dumping ground for waste is exacerbated by the increase in urbanisation. The seemingly lost sense of sustainability worries people, especially those that live near rivers. They will be the first to experience the adverse effects and benefits of river development. Hence, it is imperative to 
consider riverside communities during river planning, as they are the primary users of rivers.

The living experiences of a riverside neighbourhood have provided its communities with exposure to water-related risks such as river pollution and flood. Since the adverse effects hit their home, the residents felt the need to protect their environment as their lives would be affected. Their lives refer to the social norms that they practised, which enabled them to face disturbance together. In other words, they share the same fate (Norris et al., 2008). A wide range of meaning and interpretation of sustainability has dominated various fields (Harun, 2017). In the context of this study, sustainability is reflected through their daily practices of the residents. They treasure the river as they well understood the risk they will face should the river be taken care of improperly. The small acts, when collectively practised, can potentially alleviate river degradation. The lack of considering their living experience in the planning of river development results in mismatched outcomes.

Mismatches can be avoided, and more holistic plannings can be ensured in upcoming river developments should the voice of those communities are taken into account. The inclusion of riverside communities in river planning is in agreement with Sustainable Development Goals 11 (SDG11), which highlights their contribution towards sustainability due to their knowledge of the rivers that are their home. It is hoped that with their involvement, water sources can be improved, and the sources' importance, which is highlighted in SDG6, can be brought to attention. In conclusion, riverside communities are essential to the betterment of their rivers as they can aid in creating sustainable river environments based on their life experience in the neighbourhood.

\section{RESEARCH BACKGROUND}

Previous studies regarding rivers in Malaysia were mainly focused on addressing river governance (Chan, 2005), river management (Elfithri et al., 2011), riparian ecosystems (Omar \& Sohaili, 2015) and waterfront designs (Md. Yassin et al., 2017), and not many of them highlighted the social aspect of riverside communities. The absence of attention was probably because riverside communities are often made of slums. Nevertheless, those communities are still crucial as they often interact with their environment.

This study considered riverside communities as crucial in developing rivers into a sustainable environmental feature, as the communities are knowledgeable on what is needed to accommodate their lives. They live closest to rivers and are the most exposed to river issues (Chiang, 2018), and these facts make them the most resourceful about their well-being. However, for this study to be purposeful, the considered riverside community had to be the one that legally owned its land. 
Rohana Mohd Firdaus, Mohd Hisyam Rasidi, Ismail Said

Components of River Sustainability Through Community's Experiences in Riverside Neighbourhood

\section{METHOD}

Semi-structured questionnaires were given to a community of 121 residents who lived in Skudai River's vicinity in Kg. Pertanian, Kulai, Johor. Each questionnaire consisted of 28 questions divided into four sections: river issues, river management, community's roles, and residents' neighbourliness. These four sections were deduced from the literature of river studies, in which communities are the end-users. The five-point Likert scale that ranged from 'Strongly disagree' to 'Strongly agree' was used in the questionnaires, with added space for them to express any concern or opinion regarding the section. These responses help describe the intricacies of lived experience, which often fails to be captured (Boyer et al., 2016). For now, qualitative data remains another topic to be studied.

The pilot study showed that the scale made it easier for the respondents to answer because the choices were straightforward. They also seemed more convinced with their responses because of the scale. The questionnaires' answers were inputted in Excel and then exported into SPSS for Principal Component Analysis. The data reduction technique was employed to help capture significant components that were pertinent to the objective. Results from the rotated component matrix are explained in the discussion section.

\section{Site Selection}

This study was conducted in Kg. Pertanian, Kulai, Johor, in which lies the Skudai River. Kg. Pertanian is surrounded by multiple lands, which include domestic, industrial and residential lands. Figure 1 illustrates the setting of the site.

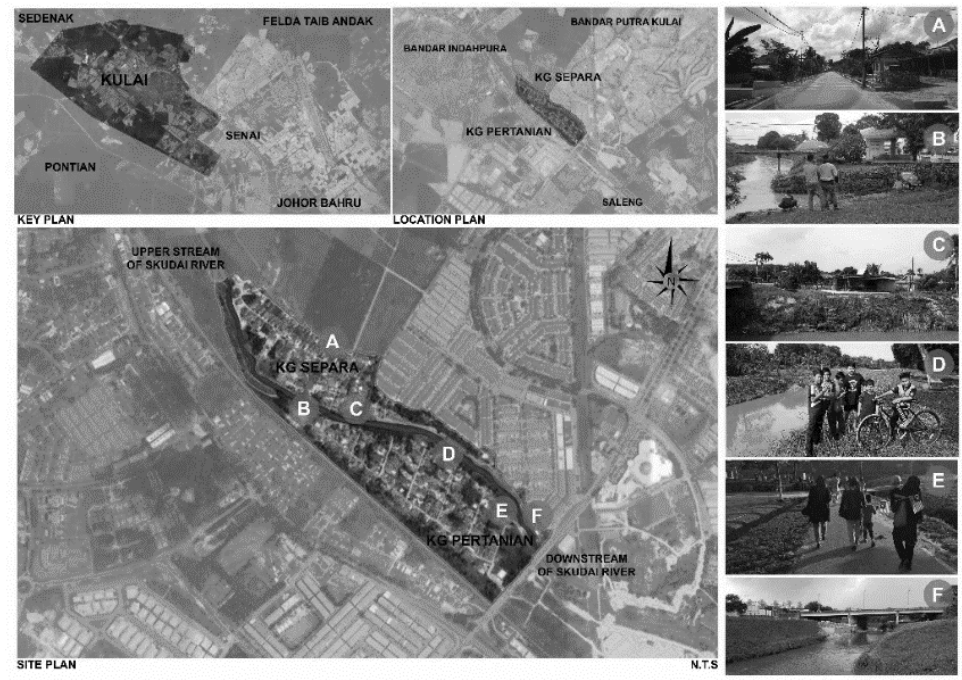

Figure 1: The site of study and its surrounding 
The residents of Kg. Pertanian were under the careful supervision of the Department of Irrigation and Drainage (DID) because of the proximity. The distance of the main road that connected the office of the department and $\mathrm{Kg}$. Pertanian was only $1.4 \mathrm{~km}$ (an 18-minute walk). Because of the DID's efforts, the residents had substantial exposure to the Skudai River. Unlike slums, the community in Kg. Pertanian legally owned the land that they resided on, as they had a land grant.

At first, site visits were carried out frequently at random times to gain familiarity. Secondly, meetings with the head of the village and the residents were conducted to establish rapport. Finally, cooperation was gained to conduct data collection. They were found to be resourceful regarding their neighbourhood, and their resourcefulness could be attributable to their lengthy residency. It should be noted that resourcefulness is essential in establishing a sustainable neighbourhood for riverside communities.

\section{RESULTS AND DISCUSSION}

Table 1 illustrates the rotated component matrix, which only retained six components of the riverside community: 1) river issues, 2) river management, 3 ) river environment, 4) community attachment, 5) participation and awareness, and 6) river development. Each component had factors, and each factor had a value known as factor loading. Factors with factor loadings above 0.7 were considered strong, while those with factor loadings of 0.5-0.7 were considered weak. Those below 0.5 were insignificant, and therefore, were allowed to be disregarded. These components are further discussed in the following sections.

Table 1: Strong factors in each component

Rotated Component Matrix

\begin{tabular}{|c|c|c|c|c|c|c|}
\hline & \multicolumn{6}{|c|}{ Component } \\
\hline & 1 & 2 & 3 & 4 & 5 & 6 \\
\hline River pollution & .897 & & & & & \\
\hline Flood experience & .866 & & & & & \\
\hline Health problem & .839 & & & & & \\
\hline Maintenance & .825 & & & & & \\
\hline River sustainability & & .786 & & & & \\
\hline Satisfaction & & .759 & & & & \\
\hline Community \& agency & & .750 & & & & \\
\hline Concreted river & & .736 & & & & \\
\hline Community commitment & & .710 & & & & \\
\hline Familiarity with houses & & & .856 & & & \\
\hline Adaptation to changes & & & .780 & & & \\
\hline
\end{tabular}


Rohana Mohd Firdaus, Mohd Hisyam Rasidi, Ismail Said

Components of River Sustainability Through Community's Experiences in Riverside Neighbourhood

\begin{tabular}{llll} 
Neighbourliness & .774 & & \\
\hline Familiarity with river & .728 & & \\
\hline Public apathy & .803 & & \\
\hline Sense of attachment & .759 & & \\
\hline Community awareness & \multicolumn{2}{l}{.858} & \\
\hline Community participation & \multicolumn{2}{l}{.826} & \\
\hline Natural river & & -.701 \\
\hline Man-made infrastructure & & .579
\end{tabular}

The first discussion section is on component number 1 , which is river issues. It is separated from component number 2, which is river management and the second discussion section. Component number 2 is considered as the response to the river issues. Component numbers 3 to 6 are discussed together in the third discussion section, which details the uses of the neighbourhood as a shared environment.

\section{River Issues}

The residents faced four river issues. The first issue was river pollution (0.897) due to the discharge from domestic uses. They claimed that the discharge came from upstream industries and flowed through the neighbourhood's river. It was out of their control because the source of the river pollution was external, and they had to face the consequences. The second issue was flooding $(0.866)$, which happened every time there was heavy rain before 2006 . The water body was not adequate in containing the heavy rainfall, resulting in flooding in the neighbourhood. The worst flood was in 2004, with a water level of approximately 3 meters reaching their rooftops. The residents had to evacuate their neighbourhood and went to a neighbouring community hall. Floods kept happening until the river was widened and deepened, and since the modification, no flood has occurred, which shows that the modification was successful. The third issue was health problems due to river pollution (0.839), and the fourth issue was maintenance (0.825). An example of maintenance was grass cutting at the riverbank, which the stakeholder entirely handled. The complete management by the stakeholder caused the community to be reliant on the stakeholder. The community believed that the stakeholder was contracted for maintenance and operated with their SOP.

Despite these issues, the people continued to reside in the neighbourhood. A study by Fattah et al. (2020) found that the residents of a neighbourhood stay because of tenure ownership and perception of neighbourhood quality. However, the riverside community's residence is related to the community's ability to cope with disturbances. The ability refers to the community's resource or capability due to the stakeholder's involvement at times 
of need. The exposure to the river issues highlights the community's reliance on the stakeholder and their efforts, which has eased the community's living. This finding is parallel to that of Magis (2010), which shows that a community that faces challenges develops resources to cope with the situations. Despite that, the residents remarked that the norms in their neighbourhood were what made them appreciate their life. Social interaction became the essence of their adaptability because it made the neighbourhood harmonious. The interaction aspect is explained in the subsection of 'Riverside Neighbourhood as a Shared Environment'. This section only explains the concerns of the community and their impact of river issues on the residents' lives.

\section{River Management}

River management, which is the second component, involved maintenance and awareness programmes. Stakeholder's involvement with the neighbourhood was found to benefit the residents by enhancing their awareness and knowledge of their river. The residents also felt satisfied with the stakeholder's services $(0.759)$. The satisfaction is evident from their commitment $(0.710)$ to the programmes organised by the stakeholder. Cooperation between the two actors has defined their relationship (0.750), which is necessary for overall river management to be successful, according to Chan (2012).

Grass cutting is a type of maintenance essential to be addressed because its inconsistency commonly fails river management (Harun et al., 2017). The residents showed that they cared about nature and believed that the process did not compromise the value of the river $(0.786)$. In other words, they were confident that the sustainability of the river was guaranteed, and the action was only to ensure the neatness of the neighbourhood and not to degrade the river's value. Besides being aesthetically neat, cut grass also symbolises harmony, as Asakawa et al. (2004) highlighted that aesthetically pleasing scenery connects human with nature. The connection between the community and the river is important in achieving sustainability.

However, this result shows a conflict of preference because the residents also believed that a concrete river could solve the river issues $(0.736)$. The residents' preference for a concreted river was potentially driven by the frequent floodings and the fact that a concreted river can channel floodwater. Despite their preference, the stakeholder only widened and deepened the river because they were appropriate for the neighbourhood. The stakeholder's actions show that the stakeholder only did what was necessary to prevent flooding from happening again. The residents' inaction was due to their incapability of adequately maintaining their river, which resulted in reliance on the stakeholder. These findings showed that the stakeholder's ability to act accordingly to the residents' needs influenced their lives in the neighbourhood. 
Rohana Mohd Firdaus, Mohd Hisyam Rasidi, Ismail Said

Components of River Sustainability Through Community's Experiences in Riverside Neighbourhood

\section{Riverside Neighbourhood as a Shared Environment}

The third component is the neighbourhood's environment, which included the residents' familiarity, ability to adapt to change, and neighbourliness. It was found that the residents were familiar with neighbours' houses $(0.856)$ and the river $(0.728)$ because they have been staying there for extended periods, 21 years on average. Their neighbourliness (0.774) was formed through the relationships established throughout their length of stay. It is shown through the interactions that often happened at communal spaces such as the community hall, the mosque and riverside walkways. These spaces can be considered important social spaces as Ujang (2016) stated that places where interactions often occur could be considered as such. Their interactions bonded them through their participation (0.826) in communal activities in the spaces they shared. Because they were safeguarding their home, a bond within their neighbourhood was fostered, and a common understanding among them was instilled. This result is parallel to the findings in Ling and Chiang (2018) 's study, in which it is stated that residents that know each other for a long time contribute to their capability to unite and create an understanding of their neighbourhood. Without being cohesive towards a positive value, sustainability is difficult to achieve. It requires collective action to ensure that the general river environment is sustainable. Furthermore, the results show that they were able to adapt to changes (0.780); for example, physical river changes such as the modified water body, which now can prevent flooding. Their adaptability was due to the shared experiences and the beneficial changes. The shared experiences throughout their stay led to the fourth component, attachment.

The fourth component is attachment, which is related to the community's feeling towards river development and public apathy. It was found to be closely related to the built environment, which one has grown familiar with and develops memories. The residents were connected to their neighbourhood because it is where they shared an environment for everyday-life interactions. As mentioned before, their interactions bonded them and created a common understanding. This understanding was put to the test when a discussion with the community turned chaotic as they expressively disagreed when asked if their river was closed or removed. The disagreement shows that they preferred the river as it was because that was what they were most familiar with, indicating they were emotionally attached to it (0.759). This finding was supported by Norris et al. (2008) 's finding, which stated that the attachment they feel to a place implies an emotional connection between the residents and their surrounding. It offers the opportunity to reduce public apathy $(0.803)$ because there are users that care about the environment.

The fifth component is the community's participation and awareness, which have been mentioned in previous paragraphs. It was discovered that these two are tied as one component based on the communal activities. For example, 
the community have annual activities such as Maulidur Rasul and Independence Day Celebrations, which allowed them to gather and unite. Their awareness of the upcoming activities (0.858) ensured their participation (0.826). These activities took place at the mosque, court, community hall and riverside. These places were public and were shared among them. Their participation led to conversations as an act of interaction that included the sharing of emotions. It has allowed them to be socially connected (Nemeth \& Olivier, 2017). They also developed a sense of attachment to their neighbourhood through the sharing of emotions, as previously discussed. This finding shows that the bond was between the residents and the neighbourhood they shared throughout their lives.

The sixth component is about river development, which was more pertinent to stakeholder's management, and thus, it was out of the community's capability. Because of this, the residents showed little concern for it. The little concern was also because of the residents' view on the development itself, which was often associated with heavy construction (0.579). This view was somewhat right; as highlighted by Chan (2012), river development concerns the physical aspects of man-made infrastructures, such as constructions for flood measures. Interestingly, it contradicts the natural river $(-0.701)$. This result confirms the second component, which portrays different preferences between the concrete and natural rivers. The finding tells that the changes that benefited them were welcomed in their neighbourhood as they had experienced floods. This further emphasises the importance of their environment-sharing experiences in the riverside neighbourhood. Therefore, incorporating the residents' experiences into decision-making processes is potentially helpful in understanding their needs and preferences for a sustainable river environment.

\section{CONCLUSION}

The community's experiences in the riverside neighbourhood can be understood through six numbered components, as illustrated in Figure 2. They are further reduced into three subjects, as discussed previously. 
Rohana Mohd Firdaus, Mohd Hisyam Rasidi, Ismail Said

Components of River Sustainability Through Community's Experiences in Riverside Neighbourhood

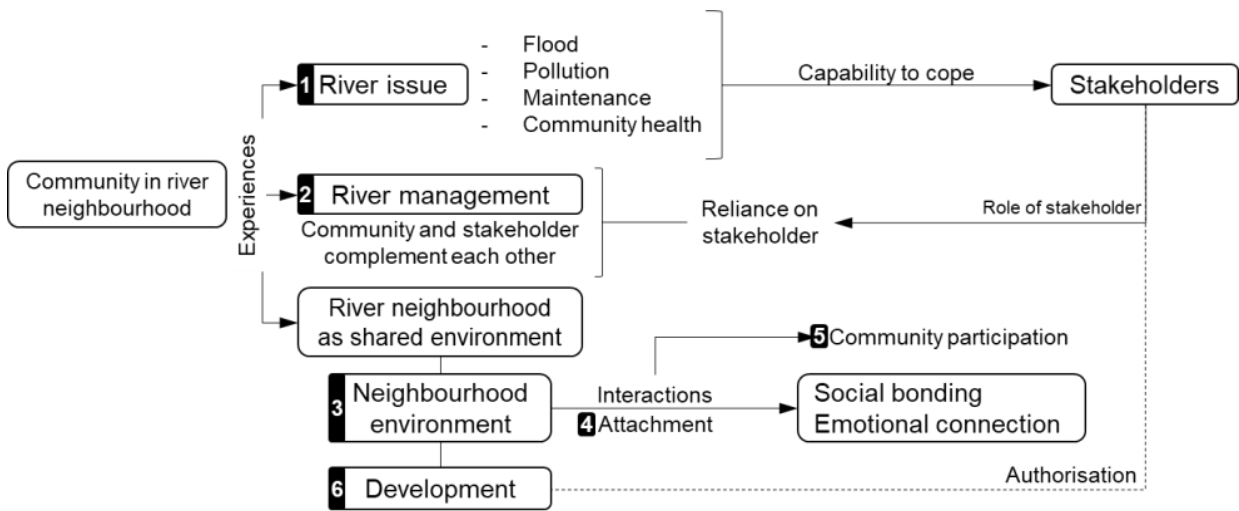

Figure 2: Triangulation of the six components in understanding the experiences of a riverside neighbourhood

This study has shown that river issues moulded the resources that the community needed to face disturbances. The stakeholder, who had authority over the river, played a role in providing resources to the community. The river issues acted as a challenge for the community to develop the capability through exercising their resources. Their river management further proved that both actors' cooperation was necessary for river sustainability. The residents' experiences defined how they perceived the river management, which led to their reliance on the stakeholder for the benefits. It means that the influence from their experience is manifested in their neighbourhood environment. It comprised of their familiarity and neighbourliness that were derived from the social interaction they had. The collectively shared norm encouraged them to have a sense of appreciation that would make them feel attached to their home. The appreciation strengthened their connection with nature, and this connection is imperative to sustainability.

This study may act as guidance for the Department of Irrigation and Drainage (DID) and possibly provide some insight to the Ministry of Housing and Local Government in the future planning of community housing, particularly for riverside communities. The values practised by the riverside community can be considered in policy-making as that community is the closest to the river. The proximity makes the residents more considerate towards the river as it affects their everyday lives. The inclusiveness in decision-making emphasises the importance of the combination of the 'top and bottom' approach. Despite the constant change in the community's view, this study serves as a base for understanding riverside communities' experiences in their neighbourhoods. 


\section{REFERENCES}

Åberg, E. U., \& Tapsell, S. (2013). Revisiting the River Skerne: The long-term social benefits of river rehabilitation. Landscape and Urban Planning, 113, 94-103. doi:https://doi.org/10.1016/j.landurbplan.2013.01.009

Asakawa, S., Yoshida, K., \& Yabe, K. (2004). Perceptions of urban stream corridors within the greenway system of Sapporo, Japan. Landscape and Urban Planning, 68(2), 167-182. doi:https://doi.org/10.1016/S0169-2046(03)00158-0

Boyer, R., Peterson, N., Arora, P., \& Caldwell, K. (2016). Five Approaches to Social Sustainability and an Integrated Way Forward. Sustainability, 8, 878. doi:10.3390/su8090878

Chan, N. W. (2005). Sustainable management of rivers in Malaysia: Involving all stakeholders (Vol. 3).

Chan, N. W. (2012). Managing Urban Rivers and Water Quality in Malaysia for Sustainable Water Resources. International Journal of Water Resources Development, 28(2), 343-354. doi:10.1080/07900627.2012.668643

Chiang, Y.-C. (2018). Exploring community risk perceptions of climate change - A case study of a flood-prone urban area of Taiwan. Cities, 74, 42-51. doi:https://doi.org/10.1016/j.cities.2017.11.001

Deng, X., \& Xu, Y. (2018). Degrading flood regulation function of river systems in the urbanisation process. Science of The Total Environment, 622-623, 1379-1390. doi:https://doi.org/10.1016/j.scitotenv.2017.12.088

Elfithri, R., Toriman, M., Mokhtar, M., \& Juahir, H. (2011). Perspectives and Initiatives on Integrated River Basin Management in Malaysia: A Review (Vol. 6).

Everard, M., \& Moggridge, H. L. (2012). Rediscovering the value of urban rivers. Urban Ecosystems, 15(2), 293-314. doi:10.1007/s11252-011-0174-7

Eze, P. N., \& Knight, J. (2018). A geomorphological characterisation of river systems in South Africa: A case study of the Sabie River. Physics and Chemistry of the Earth, Parts $A / B / C$. doi:https://doi.org/10.1016/j.pce.2018.01.001

Fattah, H., Badarulzaman, N., \& Ali, K. (2020). NEIGHBOURHOOD QUALITY ASSESSMENT: A VIEW OF TENURE OWNERSHIP AND MOBILITY DECISIONS IN PENANG, MALAYSIA. PLANNING MALAYSIA, 18. doi:10.21837/pm.v18i11.712

Harun, N. Z., Mansor, M., \& Noh, S. (2017). The benefits of river indicators to assess the ecological status of IIUM campus. PLANNING MALAYSIA JOURNAL, 15. doi:10.21837/pmjournal.v15.i6.237

Jiang, Y., Zevenbergen, C., \& Ma, Y. (2018). Urban pluvial flooding and stormwater management: A contemporary review of China's challenges and "sponge cities" strategy. Environmental Science \& Policy, 80, 132-143. doi:https://doi.org/10.1016/j.envsci.2017.11.016

Kumar, P., Masago, Y., Mishra, B. K., \& Fukushi, K. (2018). Evaluating future stress due to combined effect of climate change and rapid urbanisation for Pasig-Marikina River, Manila. Groundwater for Sustainable Development, 6, 227-234. doi:https://doi.org/10.1016/j.gsd.2018.01.004

Lanzoni, S., Ferdousi, A., \& Tambroni, N. (2018). River banks and channel axis curvature: Effects on the longitudinal dispersion in alluvial rivers. Advances in 
Rohana Mohd Firdaus, Mohd Hisyam Rasidi, Ismail Said

Components of River Sustainability Through Community's Experiences in Riverside Neighbourhood

Water

Resources,

113

$55-72$

doi:https://doi.org/10.1016/j.advwatres.2017.10.033

Ling, T.-Y., \& Chiang, Y.-C. (2018). Strengthening the resilience of urban retailers towards flood risks - A case study in the riverbank region of Kaohsiung City. International Journal of Disaster Risk Reduction, 27, 541-555. doi:https://doi.org/10.1016/j.ijdrr.2017.11.020

Magis, K. (2010). Community Resilience: An Indicator of Social Sustainability. Society \& Natural Resources, 23(5), 401-416. doi:10.1080/08941920903305674

Mann, R. (1973). Rivers in the City: Praeger.

Md. Yassin, A., Eves, C., \& McDonagh, J. (2010). An evolution of waterfront development in Malaysia.

Md. Yassin, A., Ramlan, R., \& Razali, M. (2017). Assessing opportunities and challenges in waterfront development in Malaysia (Vol. 23).

Nemeth, D. G., \& Olivier, T. W. (2017). Chapter 1 - Resilience: Defined and Explored. In D. G. Nemeth \& T. W. Olivier (Eds.), Innovative Approaches to Individual and Community Resilience (pp. 1-23). San Diego: Academic Press.

Norris, F., Stevens, S., Pfefferbaum, B., Wyche, K., \& Pfefferbaum, R. (2008). Community Resilience as a Metaphor, Theory, Set of Capacities, and Strategy for Disaster Readiness. American journal of community psychology, 41, 127-150. doi:10.1007/s10464-007-9156-6

Omar, S. R., \& Sohaili, J. (2015). River Reserves: Understanding Its Significance as a Prevention Measure of River Pollution. Paper presented at the 3rd Int. Conf. Water Resour.-ICWR 2015.

Rufat, S., Tate, E., Burton, C. G., \& Maroof, A. S. (2015). Social vulnerability to floods: Review of case studies and implications for measurement. International Journal of Disaster Risk Reduction, 14, 470-486. doi:https://doi.org/10.1016/j.ijdrr.2015.09.013

Solins, J. P., Thorne, J. H., \& Cadenasso, M. L. (2018). Riparian canopy expansion in an urban landscape: Multiple drivers of vegetation change along headwater streams near Sacramento, California. Landscape and Urban Planning, 172, 37-46. doi:https://doi.org/10.1016/j.landurbplan.2017.12.005

Ujang, N. (2016). Defining Place Attachment in Asian Urban Places through Opportunities for Social Interactions. Environment-Behaviour Proceedings Journal, 1(1), 28-35. doi:10.21834/e-bpj.vli1.191

Weil, K. K., Cronan, C. S., Meyer, S. R., Lilieholm, R. J., Danielson, T. J., Tsomides, L., \& Owen, D. (2018). Predicting stream vulnerability to urbanisation stress with Bayesian network models. Landscape and Urban Planning, 170, 138-149. doi:https://doi.org/10.1016/j.landurbplan.2017.11.001

Received: $4^{\text {th }}$ January 2021. Accepted: $25^{\text {th }}$ April 2021 